\title{
A Mechanistic Review of Nicotine Toxicity with Recent Updates
}

\author{
Milad $\mathrm{A}^{1}$ and Zahra $\mathrm{A}^{2 *}$ \\ ${ }^{1}$ Department of basic science, University of Tabriz, Iran \\ ${ }^{2}$ Department of basic science, University of Shushtar, Iran
}

*Correspondence: Zahra Ahmadi, Department of basic science, Faculty of veterinary medicine, University of Shushtar, Khuzestan-Iran; Email:

\begin{tabular}{|c|}
\hline Research Article \\
Volume 4 Issue 2 \\
Received Date: March 15, 2019 \\
Published Date: April 19, 2019 \\
DoI: $10.23880 /$ ijbp-16000155 \\
\hline
\end{tabular}
zahra.ahmadi9996@gmail.com

\begin{abstract}
There are concerns about the spread of cigarette smoking and nicotine is the most harmful agent in cigarette smoke. The statics show the growing use of cigarette smoking. Nicotine is an alkaloid and is present in the leaves of tobacco where it acts as a botanical insecticide. It represents $90 \%$ of total alkaloid in cigarette smoke. Osteoporosis, lung and kidney injuries, diseases of respiratory and cardiovascular systems, and increased risk of malignancy are just a few of toxic effects of nicotine on the body. Nicotine exerts its harmful effects via oxidative stress pathway, so that it enhances the production of reactive oxygen species (ROS) and then negatively affects different organs and systems of body. This review provides a comprehensive review of detrimental effects of nicotine on the body and then describes its mechanism of toxicity.
\end{abstract}

Keywords: Nicotine; Reactive oxygen species; Toxicity; Organs; Systems

Abbreviations: AST: aspartate aminotransferase; ALT: alanine aminotransferase; ALP: alkaline phosphatase; NO: Nitric oxide; PLP: Pyridoxal phosphate; LDL: Low density lipoprotein; HDL: High density lipoprotein; VLDL: Very low density lipoprotein; SOD: Superoxide dismutase; CAT: Catalase; GSH: Glutathionereductase; ALP: Alkaline phosphatase; ROS: Reactive oxygen species; MDA: Malondialdehyde; iNOS: inducible nitric oxide synthase; TNF: Tumor necrosis factor; CRF: Chronic renal failure; NSCLC: Non-small cell lung cancer; EMT: Epithelial-mesenchymal transition; nAChR: Nicotine acetylcholine receptor; BBB: Blood-brain barrier; ER-?] Estrogen-receptor beta; NGF: Nerve growth factor; FSH: Follicle-stimulating hormone; LH: Luteinizing hormone; BTB: Blood-testis barrier; IVF: In vitro fertilization; CVD: Cardiovascular disease.

\section{Introduction}

During recent years much attention has been performed towards the toxicity of compound and finding naturally occurring agents for overcoming their toxicity and nicotine is one of the toxic agents [1-6]. Nicotine has harmful effects on health and its using is increasing [7]. The mortality from cigarette smoking is approximately 178000 women in United States, so that lung cancer, heart disease and chronic lung disease are three causes of death in smoking women [8]. Surprisingly, more than $90 \%$ of smokers are interested in quitting and almost one in three try cessation each year $[9,10]$. The first few weeks after cessation, nicotine withdrawal syndrome is most intense and creates difficult condition and that is the reason of short-living cessation [11,12]. The most harmful compound that is found in the cigarette smoke, is nicotine 


\section{International Journal of Biochemistry \& Physiology}

[13]. Nicotine is present in the leaves of tobacco where it has role as a botanical insecticide (Figure 1) $[14,15]$. A medium tobacco rod has 10 to $14 \mathrm{mg}$ of nicotine and during smoking, 1 to $1.5 \mathrm{mg}$ of nicotine is systematically absorbed $[16,17]$. The nicotine in tobacco is mostly in the form of levorotary (S)-isomer and a little part (0.1 to $0.6 \%)$ of whole nicotine content is (R)-nicotine [18]. Because of using plant-derived nicotine, chemical reagents and pharmaceutical formulations of (S)-nicotine have a similar content of (R)-nicotine [18]. Due to occurring racemization during combustion, it has been reported that more than $10 \%$ of nicotine in smoke is (R)isomer $[19,20]$. In this review, we investigate the adverse impacts of nicotine on different organs and systems of body and then, explain its mechanism of toxicity.

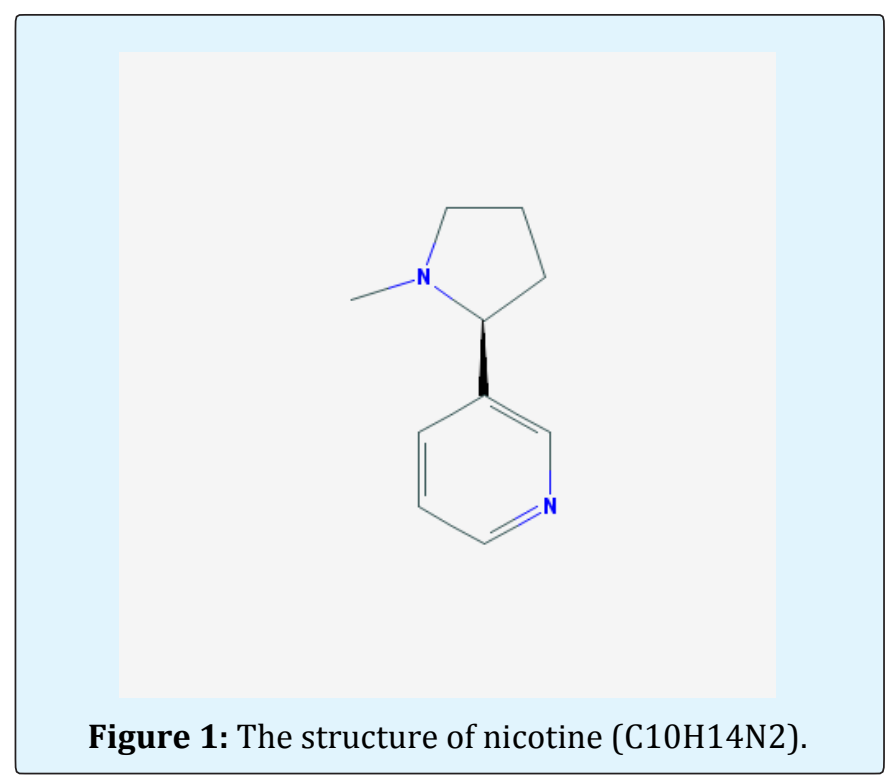

\section{Effects on Liver}

During the smoking, nicotine is absorbed via lungs and is immediately metabolized in liver and then, exerts three major harmful effects on the liver: toxic (direct or indirect), immunological and oncogenic [21-24]. The harmful effects of nicotine on the liver include histopathological alterations, changes in the serum level of enzymes showing liver activity (such as aspartate aminotransferase (AST), alanine aminotransferase (ALT) and alkaline phosphatase (ALP)), alterations in the antioxidant enzymes of liver tissue and serum level of nitric oxide (NO). Elevated diameter of hepatocytes and central vein [23], accumulation of lipids and steatosis in the liver [24] are histopathological changes resulting from nicotine exposure. These changes are maybe due to the increased metabolic activity of cells for removing toxins from body during the toxification process [25]. AST and
ALT are involved in the gluconeogenesis and aminoacid metabolism. They function in a pyridoxal phosphate (PLP)-dependent manner. Besides, they accelerate the metabolism of glucose and proteins. Liver metabolic syndrome, atherogenesis and type I and II diabetes can increase the activity of these enzymes [26-30]. Similarly, nicotine increases the level of AST and ALT [23,31] demonstrating the increased activity of liver that maybe again is due to eliminating this toxic agent. ALP plays a significant role in the metabolism of phosphate and also catalyzes the dephosphorylation of proteins, nucleic acids and different small molecules. It is a biomarker of liver diseases [32]. It has been shown that nicotine administration increases the level of ALP [23,21]. Furthermore, ALP serves as a biomarker of cellular adjustment to the various injuring factors [33,34]. Increased level of NO is another adverse effect of nicotine usage. The secretion and release of noradrenaline in paraventricular nucleus and amygdale via a direct impact on the nuclei of solitary tract and N-methyl-D aspartate are triggered by nicotine that subsequently induces the generation of NO and neuronal noradrenergic activity [35]. Nicotine can increase the serum levels of cholesterol, triglyceride, LDL and VLDL. Furthermore, it diminishes the levels of HDL [36]. The levels of superoxide dismutase (SOD), catalase (CAT), glutathione-reductase (GSH) and glutathione-peroxidase enzymes of liver tissue decrease at the result of nicotine exposing demonstrating the decreased level of antioxidant capacity of liver [36].

\section{Effects on Bone}

Bone is one of the strong connective and high specialized tissues composed of organic and inorganic elements [37-41]. Changes in the physical and physiological conditions lead to the different functions of specialized cells in bone. Osteoblasts, osteoclasts and osteocytes are specialized cells of bone which respectively involve in the formation, resorption and remodeling of bone [42]. As well as increased risk of malignancy, osteoporosis and diseases of respiratory and cardiovascular systems are adverse effects of nicotine on the body (43-48), nicotine affects negatively the wound healing and fracture repair [49-58]. Decreased bone mineral density, diminished blood supply, decreased number of bone forming cells and increased absorption of carbon monoxide are factors that cause skeletal defects $[59,60]$. The initial inflammatory response, soft callus formation, hard callus formation and bone remodeling are four steps of bone healing [61]. Cytokines, growth factors, prosteogenic and angiogenic factors, inflammatory cells, vascular cells, osteochondral progenitors and osteoclasts adjust these four events [61-65]. Naturally, any agent that disturbs one of the mentioned factors, can produce 


\section{International Journal of Biochemistry \& Physiology}

defects in bone. It has been shown that men who start smoking in young adulthood, have poorer development in their areal bone mineral density compared to the nonsmokers [66]. Also, the risk of hip fracture is higher in both male and female smokers [67]. Liang et al investigated the impacts of nicotine on the rat primary osteoblasts [68]. Their data showed that nicotine remarkably reduces the proliferation of osteoblasts. Besides, nicotine elevates the activity of alkaline phosphatase (ALP). Similarly, Fang et al demonstrated that nicotine has inhibitory effects on the cellular proliferation and stimulatory effects on ALP activity in a dose-dependent manner in rat osteoblastic osteosarcoma cells [69]. Also, nicotine stimulates apoptosis in osteoblasts [70].

\section{Effects on the Kidney}

After the absorption of nicotine, it circulates in the body and rapidly distributes in different tissues. Most of the nicotine is metabolized by liver. Also, kidneys and lungs are involved in the metabolism of nicotine [71]. Nicotine results in the activation of cytochrome P-450 dependent monooxygenases in the liver. Then, the cotinine is formed that is considered as an important marker of nicotine intake [72]. Eliminating the cotinine produced by the liver is performed by kidney. Oxidative stress is the major pathway that nicotine uses to stimulate its harmful effects on the kidney [73]. Nicotine increases the generation of reactive oxygen species (ROS) resulting in the DNA damage, cancer, heart diseases, brain dysfunction and progression of ageing process [74]. Due to the increasing usage of cigarette, the injuries in the renal are increasing [75].

The increased serum levels of urea and creatinine are considered as the markers of renal injury [76]. Nicotine leads to the increased serum levels of urea and creatinine [77]. Acute renal injuries, dilation and destroying the cells lining proximal and distal convoluted tubules are the major histopathological changes of kidney caused by nicotine [78]. Lipid peroxidation is an important contributor of the loss of cell function under oxidative stress conditions [79]. This condition might lead to the renal injury. Increased level of malondialdehyde (MDA) and decreased level of GST and GSH have been reported in the kidney of rats exposed to the nicotine.

Another way that nicotine uses to produce kidney injury, is inflammation. Exposing to nicotine stimulates macrophages to release pro-inflammatory mediators. Then, they activate neutrophils to synthesize free radicals, elastase and inflammatory cytokines including TNF-? 6 and IL-1b [80]. It has been shown that inflammatory cytokines have an important role in the development and progression of chronic renal failure (CRF) [81]. Zahran and Emam [77] demonstrated that exposing to the nicotine is associated with increased concentrations of mentioned cytokines. NF-kB network has a role in inflammatory, autoimmune and malignant disorders [82]. It is a transcription factor which activates different inflammatory genes, resulting in cellular damage [83]. The increased level of ROS stimulates the generation of inflammatory cytokines, resulting in the activation of NF$\mathrm{kB}$ signaling mechanism [84]. The activation of NF-kB leads to the transcription of several genes such as IL-6, TGF-B1 and VEGF. Next, the proteins produce NO by promotion of inducible nitric oxide synthase (iNOS) gene, synthesize free radicals and activate apoptosis via caspase resulting in the kidney injury [85]. Janus and coworkers [86] showed that nicotine stimulates apoptosis by activation of caspase 3 via induction of NF-kB signaling mechanism. There are findings about the elevated level of protein expression of NF-kB, caspase-3 and NO [77]. Chattopadhyay and coworkers [36] mentioned similar results about the effects of nicotine on the kidney.

\section{Effects on the Lung}

Although lungs have a major role in the absorption of nicotine, this organ has not been extensively studied. There are evidences about the role of nicotine in increasing the proliferation of non-small cell lung cancer (NSCLC). Xuemei and coworkers [87] investigated this role of nicotine. They showed that nicotine increases the proliferation of NSCLC cell via nicotine-miR $99 \mathrm{~b} / \mathrm{miR}-$ 192-FGF R3/R1 regulatory network. It has been shown that nicotine (as an addictive component of tobacco smoke), is not able to begin tumorigenesis in humans and rodents [88], but it can increase the growth and metastasis of different tumors such as lung cancer. This phenomenon is the result of stimulation of cell-cycle progression, angiogenesis and epithelial-mesenchymal transition (EMT) [89-91]. Furthermore, the promotion of EMT, invasion and migration of NSCLC cells have been reported at the result of exposing to the nicotine which are through regulating STMN-3 and GSPT1 genes in an ID1-dependent manner [92]. A similar study also has demonstrated the role of nicotine in the promotion of growth and metastasis of lung cancer in mouse xenograft models [93].

Nicotine increases the proliferation of lung tumor cells via binding to the nicotine acetylcholine receptors (nAChRs). These receptors are pentameric ligand-gated ion channels that located on the membranes of different cells in lung tumor cells. Nicotine is the agonist of nAChR that through binding, stimulates a change in the conformation of nAChR. This conformation change 


\section{International Journal of Biochemistry \& Physiology}

provides the influx of sodium and calcium ions. Then, the calcium-dependent and calcium-independent downstream signaling pathways of $\mathrm{nAChR}$ are activated. It has been demonstrated that induction of these signaling pathways might result in the proliferative and antiapoptotic actions of nicotine $[91,94,96]$.

The lungs of newborn rats exposed to maternal nicotine have been studied [97]. Emphysema, increased interstitial tissue, increased number of alveolar macrophages and mast cells are histopathological changes. Also, biochemical analysis showed the increased level of MDA and decreased level of GSH at the result of exposing to nicotine.

\section{Effects on the Nervous System}

A preventable risk factor for stroke is cigarette smoking and smoking-ingested nicotine deteriorates post-stroke brain damage [98,99]. Nicotine is rapidly transported from blood to brain because it is used as a cerebral blood flow marker [100-102], so nicotine can cross the blood-brain barrier (BBB). Nicotine has analgesic and antinoceptive properties, so that it can decrease the post-operative pain scores in non-smokers and also reduces the consumption of morphine [103,104]. In neurons, conformational change and influx of sodium and calcium ions at the result of binding of nicotine to the nAChR, result in the depolarization of the cell and initiation of action potential.

Aromatase enzyme catalyzes the conversion of androgens into estrogens and nicotine inhibits its function [105]. Due to the involvement of estrogen receptor-beta (ER- $\beta$ ) in the estrogen-mediated neuroprotection and its role in the regulation of inflammasome [106-108], so decreased level of ER- $\beta$ increases the inflammasome activation. Adesky and coworkers showed that exposing to the nicotine reduces the levels of ER- $\beta$ protein [109]. Also, they showed that nicotine elevates the activation of inflammasome in the brain, so that it increases the protein levels of caspase 1 , ASC and IL-1 $\beta$.

Amygdala is a part of the mesocorticolimbic dopamine systems and is involved in the association of discrete stimuli with drugs of addiction [110]. It has been shown that the activities of amygdala and related regions including anterior cingulate cortex (ACC) and the orbitofrontal cortex (OFC) have increased in smokers [111-115]. Recently, Shen and coworkers [116] investigated the function of amygdala at the result of exposing to the nicotine. They reported the elevated activity of amygdala in the right hemisphere, but the activity of left amygdala was similar to non-smokers.

It has been reported that there is a relationship between nicotine exposure and the level of nerve growth factor (NGF). Exposing to the nicotine upregulates the NGF mRNA in embryo spinal cord neurons and its receptors in PC12 cell line [117-119]. The mechanism of releasing NGF is interesting. Airway structural cells and inflammatory cells infiltered in the bronchial mucosa physiologically release NGF [120-122]. It has been shown that exposing to the nicotine stimulates NGF release in lung fibroblasts and also elevates the levels of NGF in lung homogenates and BAL fluid [123,124]. Recently, Stabile and coworkers [125] demonstrated more obvious the relationship between nicotine usage and NGF receptors in bronchial epithelial cell line.

Developmental nicotine exposure results in the alterations in cholinergic and nervous system [126-133]. Furthermore, prenatal nicotine exposure results in the differences in brain size, and changes in dendrite, spines and specific regions of central nervous system (CNS) [134-136]. Dopamine plays a remarkable role in the normal development of nervous system. It has been shown that prenatal nicotine exposure alters the dopamine release [137-144], so regardless of increased or decreased level of dopamine, nervous system might not have an ordinary development. Recently, Morris and coworkers [145] studied the developmental nicotine exposure on the nervous system of Drosophila melanogaster larvae. They demonstrated alterations in the dopaminergic system, brain area, TH levels and number of $\mathrm{TH}+$ neurons.

\section{The Effects on the Reproductive System}

Infertility is a major health problem with harmful impacts on various psychological, social, personal and economic aspects [146]. Male factors are responsible for $50 \%$ of infertility cases. There is a relationship between smoking and infertility in men [147,148]. Decreased gametogenesis and steroidogenesis, and inhibited secretion of gonadotropin hormones are the results of nicotine usage [149]. Also, exposing to nicotine decreases testosterone release [150-152], estradiol [153,154], follicle-stimulating hormone (FSH) and luteinizing hormone (LH) [149]. The number, movement, survival and normal morphology of sperms are negatively affected by nicotine $[155,156]$. Besides, nicotine decreases the weight of testes, body and libido [151,155]. It has been reported that nicotine usage elevates apoptosis in reproductive system $[157,158]$. Other researches also mentioned nicotine as a factor of causing infertility 


\section{International Journal of Biochemistry \& Physiology}

because of its adverse effects on the sperm count, motility, morphology, viability and testicular weight $[159,160]$.

Nicotine has inhibitory effects on the CNS, so that it can prevent neural stimulus essential for the release of gonadotropins from hypophysis [161]. Also, spermatogenesis is a highly controlled process and its regulation is based on the testosterone and gonadotropins such as LH and FSH [162]. Recently, Mohammadghasemi and Jahromi demonstrated that nicotine remarkably diminishes the levels of LH and testosterone [163], so impaired spermatogenesis could be an obvious result of nicotine exposure. Also, nicotine increases the level of testicular lipid peroxidation and decreases the level of testicular antioxidant [155].

To assess more accurately the fertility status, the evaluation of sperm DNA is recommended [162]. Decreased fertility is associated to the high levels of sperm DNA damage [162]. Also, oxidative stress is known as a factor of producing single- and double-strand deoxyribunucleic acid (DNA) breaks [164,165]. Recently, Mohammadghasemi and Jahromi [163] showed that exposing to nicotine interrupts the unity of sperm chromatin. Also, nicotine enhances the generation of cholesterol, triglycerides, phospholipids and free fatty acids in the testes and enhances peroxidative damage [166].

Blood-testis barrier (BTB) is an important structure of the seminiferous epithelium that is constituted by sertoli cells. The tight junctions, desmosomes, gap junctions and basal ectoplasmic specializations reinforce this barrier $[167,168]$. Solute carrier transporters (SLC22A) are a type of influx transporters which are involved in nicotine transport system [169]. Recently, Das and coworkers [170] showed the downregulation of SLC22A at the result of exposing to the nicotine that demonstrates the attempt of testis for preventing the influx of nicotine into the testis.

What is obvious is the spread of smoking habit in young men which results in the disruption of pubertal development of Leydig cells. The development of Leydig cells is controlled by the hypothalamus-pituitary axis. Hypothalamus synthesizes gonadotrophin-releasing hormone that binds to its receptor in the pituitary and induces the secretion of LH and FSH. These two hormones have a significant role in directly or indirectly stimulating Leydig cell development [171,172]. Guo and coworkers [173] showed the decreased concentration of LH and FSH in rats exposing to nicotine. Also, as we mentioned, nicotine binds to nAChRs and exerts its effects. These receptors are mainly distributed in plant ganglion, adrenal medulla, skeletal muscle, neuromuscular junction and brain [174]. Ge, et al. [175] and Favaretto, et al. [176] confirmed the existence of nAChRs on the Leydig cells of rats.

The prevalence of smoking has increased among the women in Europe and USA [177,178]. The association between decreased fertility and smoking is not well known. Due to inhibition of aromatase enzyme activity by nicotine, the conversion of androgens into estrogens does not happen, so decreased level of estrogen and early onset of menopause in women are the results of nicotine exposure [179-187]. Nicotine disrupts the relationship between acetylcholine and its receptor and exerts its detrimental effects on placenta. This interruption results in adverse effects on blood flow, amniotic flow and transfer of nutrients. Also, it is harmful for the development of placental bed [188]. Nicotine leads to the early abortion via harmfully affecting embryo adherence to endometrium [189].

A properly prepared endometrium is necessary for the embryo implantation and quality of endometrium has a remarkable role in occurrence and continuation of pregnancy. It has been reported that the implantation rates are lower in smokers compared to the nonsmokers [190]. There are controversial results about the uterine receptivity rates of smokers and non-smokers. In a research, for evaluation of uterine receptivity in in vitro fertilization (IVF) cycles, three groups of patients provided: non-smokers, light smokers (smoking less than 10 cigarettes a day) and heavy smokers (smoking more than 10 cigarettes a day). It has been shown that the implantation rate significantly decreased at heavy smokers, but there was no difference at non-smokers and light smokers [191]. It has been demonstrated that high levels of cotinine (metabolite of nicotine) in follicular fluid is associated with higher rate of implantation failure and decreased number of live births [189].

Maternal levels of oestriol, oestradiol, human chorionic gonadotropin (hCG), human placental lactogen (hPL) and placental aromatase activity decrease in the smokers. Besides, nicotine prevents regeneration of human embryonic stem cells and binding of active adhesion molecules [192]. These effects might result in the inhibited invasion of trophoblast and unfavorable pregnancy outcomes.

Nicotine usage changes the transportation of ions in uterine fluid and epithelium [193] affecting hatching and outgrowth of blastocytes [194]. Also, it disrupts 


\section{International Journal of Biochemistry \& Physiology}

endometrial decidualization [195], prolongs gestation, prevents cervical ripening [196] and degenerates endometrium in the uterus and ovarian follicles in female rats [197]. Halder and coworkers [198] investigated the histological profile of uterine in rats exposed to nicotine. They showed decreased height of luminar epithelium, decomposition of basal layer, unregularly distribution of cells in luminar epithelium, decreased diameter of lumen in uterine glands and unregularly distribution of cells and vacuoles in glandular epithelium.

Epidemiologically, cigarette smoking is a main risk for tubal ectopic pregnancy. Animal and human researches demonstrated the effects of nicotine exposure on oviduct/fallopian tube function [199,200].

It seems that the ovarian reserve is lower in smokers. Nicotine increases the number of atretic follicles and decreases the number of corpora lutea in female rats treated with nicotine $[201,202]$. Also, it prevents the release of gonadotropins from pituitary that results in atrophy of gonadal structure and function [203]. Besides, nicotine can act directly on the ovarian morphology [202].

\section{Effects on the Cardiovascular and Hematopoietic Systems}

Cigarette smoking is considered as one of the major causes of premature cardiovascular disease (CVD) $[204,205]$. Increased plasma level of epinephrine, elevated cardiac work, myocardial contractility and increased blood pressure are the results of cigarette smoking [204]. Due to the impacts of nicotine on the vascular smooth 1 1-adrenergic receptors, the diameter of coronary arteries decreases and subsequently, coronary blood flow decreases. Also, nicotine has ischemia and arrhythmogenic effects, resulting in increased risk of sudden cardiac death in smokers compared to the nonsmokers. Besides, nicotine increases the blood pressure, but in regular smokers, there is no relationship between cigarette smoking and high blood pressure. Flouris and coworkers [206] showed that adolescents who smoke, are at the higher risk of CVD. Also, it has been reported that adolescents are more vulnerable compared to the adults [207-209].

CV health mainly depends on the vascular endothelium. Early atherosclerotic lesions result from endothelial dysfunction [210,211]. It has been demonstrated that endothelial cells are important targets of inflammatory cytokines which release from different immune and vascular cells [212]. Tumor necrosis factor (TNF) ? is one of the inflammatory cytokines that stimulates endothelial nitric oxide dysfunction, ROS generation and proliferation of vascular smooth muscle cell, leading to the endothelial dysfunction and increased risk of CVDs [115,213,214]. Liu and coworkers [215] showed that nicotine usage enhances endothelial dysfunction, vascular oxidative stress and vascular inflammation.

\begin{tabular}{|c|c|}
\hline Organ or system & \begin{tabular}{|c|} 
Major adverse effects \\
\end{tabular} \\
\hline \multirow{4}{*}{ Liver } & - Increased diameter of hepatocytes and central vein \\
\hline & - Increased level of ALP, ALT and AST \\
\hline & - Decreased level of SOD, CAT and GSH \\
\hline & - Increased level of NO \\
\hline \multirow{5}{*}{ Bone } & - Increased risk of osteoporosis \\
\hline & - Increased apoptosis \\
\hline & - Delayed healing \\
\hline & - Increased activity of ALP \\
\hline & - Increased fracture \\
\hline \multirow{4}{*}{ Kidney } & - Increased level of urea and creeatinine \\
\hline & - Increased level of cytokines \\
\hline & - Dilation and destruction of epithelial cells \\
\hline & - Increased level of MDA \\
\hline \multirow{4}{*}{ Lung } & - Increased incidence of lung cancer \\
\hline & - Emphysema and increased interstitial tissue \\
\hline & - Increased level of MDA \\
\hline & - Decreased level of GSH \\
\hline \multirow{3}{*}{ Nervous system } & - Increased activity of amygdala \\
\hline & - Induction of action potential \\
\hline & - Increased level of inflammasome \\
\hline
\end{tabular}




\section{International Journal of Biochemistry \& Physiology}

\begin{tabular}{|c|c|}
\hline & - Decreased level of ER-b \\
\hline \multirow{4}{*}{ Male reproductive system } & - Decreased level of testosterone \\
\hline & - Decreased level of LH and FSH \\
\hline & - Abnormal sperm \\
\hline & - Decreased gametogenesis \\
\hline \multirow{4}{*}{ Female reproductive system } & - Decreased level of ovarian reserve \\
\hline & - Lower uterine receptivity \\
\hline & - Disruption of endometrial decidualization \\
\hline & - Degeneration of endometrium \\
\hline \multirow{4}{*}{ Cardiovscular system } & - Endothelial dysfunction \\
\hline & - Risk factor for CVD \\
\hline & - Increased blood pressure \\
\hline & - Decresed coronary blood flow \\
\hline
\end{tabular}

Table1: Major adverse effects of nicotine on various organs and systems.

\section{Mechanism of Toxicity}

Until now, we explained the adverse effects of nicotine on the different organs and systems of body, but the route that nicotine uses to exert its effects, is interesting.

\section{Oxidative Stress}

The most important pathway that nicotine uses is oxidative stress. The proteins of cells, membrane lipids and nucleic acids are affected by high levels of free radicals [216]. Reactive oxygen species include different chemical materials such as superoxide anions, hydroxyl radicals and hydrogen peroxide. They are different in term of stability, so that superoxide or hydroxy radicals are instable, whereas hydrogen peroxide has long life with high diffusible ability. The endogenous (intracellular) and exogenous manners are the sources that can produce free radicals [217,218]. Endogenous sources include mitochondria, peroxisomes lipoxygenases, NADPH oxidase and cytochrome P450. Exogenous sources include ultraviolet light, ionizing radiation, chemotherapeutics, inflammatory cytokines and environmental toxins [219]. Oxidative stress is the imbalance between the production of free radicals and ability of antioxidant defense members [220]. As we showed, nicotine not only enhances production of ROS, but also depletes the antioxidant reserves. One of the enzymes that has an important role in neutralizing the adverse effects of ROS and nicotine, is glutathione peroxidase (GPX). To describe the role of GPX, first of all, we explain the role of glutathione (GSH). GSH owns sulfhydryl groups and has low level in mammalian tissues. GSH is vital for neutralizing free radicals. There are two forms of glutathione: reduced (GSH) and oxidized (GSSG) forms. The reduced form has electron in thiol groups of cysteine residues which gives it to the ROS to inhibit their instability. The GPX incorporates this molecule with another glutathione and produces glutathione disulfide
(GSSG). The synthesis of GSH from GSSG can be performed by glutathione reductase (GR). The concentrations of GSH and GSSG are in balance, so that total concentrations of GSH and GSSG are $90 \%$ and $10 \%$, respectively [221]. Under the oxidative stress caused by nicotine, the concentration of GSSG is much higher compared to the GSH, demonstrating the impaired antioxidant defense system.

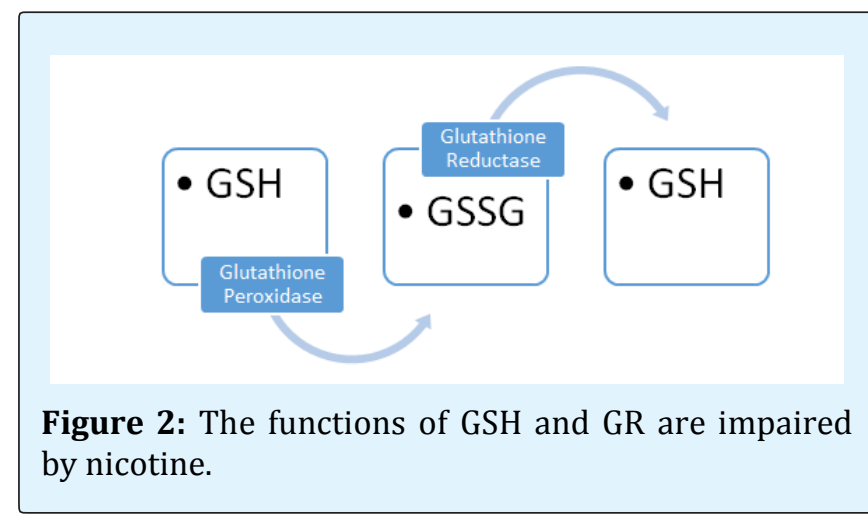

Throwing away the hydrogen peroxide from erythrocytes is performed by catalase (CAT) that shows its remarkable role. Also, CAT is one of the main enzymes of all peroxisomes. It has been shown that the levels of CAT and superoxide dismutase (SOD) decreased at the result of exposing to nicotine. The lipid bilayer that regulates the permeability of cells, is formed by polar lipids (structural components). Glycerol-based lipid is the most important component forming this bilayer. The polarity and permeability are controlled by lipids that suggests the significant role of lipids in regulating the normal condition of a membrane organelle [222]. Lipid peroxidation is one of the results of stress oxidative that is produced by nicotine toxicity. It has been shown that numerous and excessive concentrations of ROS produce 


\section{International Journal of Biochemistry \& Physiology}

damages in lipids [223]. One of the metabolites of lipid peroxidation is 4-hydroxyl-2-nonenals (4-NHE) that is so energetic. 4-NHE can regulate some signaling pathways. It has been reported that mitochondria generate 4-NHE and high level of ROS. Also, it has been shown that 4-NHEderived metabolites in mitochondria participate in the beginning and advancement of cancer [130, 224-228], so suggests the possible role of nicotine toxicity in producing cancer.

\section{Conclusion}

The smoking habit is increasing and what are obvious are the adverse effects of nicotine. Nicotine negatively affects all the organs and systems of body such as liver, kidney, nervous and reproductive and cardiovascular systems, lung and bone that we discussed these effects with details. Also, nicotine increases the synthesis of ROS and also evacuates the antioxidant defense system. Due to the lack of a comprehensive review of effects of nicotine, this review provides a platform for further research of adverse effects of nicotine exposure.

Conflict of interest: Author declares that there is no conflict of interests in the course of conducting this research.

\section{References}

1. Abdollahzadeh SS, Ashrafizadeh M (2018) Effects of Exercise on Testosterone Level, Heat Shock Protein, and Fertility Potential. Reviews in Clin Med 5(4): 1411415.

2. Ahmadi Z, Ashrafizadeh M (8019) Down Regulation of Osteocalcin Gene in Chickens Treated with Cadmium. Iranian J Toxicol 13(1): 1-4.

3. Fatemeh HD, Milad A, Roohollah SR, Elham GA, Hamid $M$, et al. (2018) Antifungal nanoparticles reduce aflatoxin contamination in pistachio. Pistachio and Health journal 6(2): 26-33.

4. Mohammadinejad R, Ahmadi Z, Tavakol S, Ashrafizadeh M (2019) Berberine as a potential autophagy modulator. J cellular physiol.

5. Mohammadinejad R, Dadashzadeh A, Moghassemi S, Ashrafizadeh M, Dehshahri A, et al. (2019) Shedding light on gene therapy: carbon dots for the minimally invasive image-guided delivery of plasmids and noncoding RNAs. J Adv Res 18: 81-93.
6. Sobhani B, Roomiani S, Ahmadi Z, Ashrafizadeh M (2019) Histopathological Analysis of Testis: Effects of Astaxanthin Treatment against Nicotine Toxicity. Iranian J Toxicol 13(1): 41-44.

7. Mackay J, Eriksen M, Eriksen MP (2001) The tobacco atlas: World Health Organization.

8. Control CFD, Prevention (1997) Cigarette smoking among adults--United States, 1995. MMWR Morbidity and mortality weekly report 46(51):1217-1220.

9. Fiore MC, Jorenby DE, Baker TB, Kenford SL (1992) Tobacco dependence and the nicotine patch: clinical guidelines for effective use. Jama 268(19): 26872694.

10. Fiore MC, Novotny TE, Pierce JP, Hatziandreu EJ, Patel KM, et al. (1989) Trends in cigarette smoking in the United States: the changing influence of gender and race. Jama 261(1): 49-55.

11. Hughes JR, Higgins ST, Hatsukami D (1990) Effects of abstinence from tobacco. Research advances in alcohol and drug problems: Springer, pp: 317-398.

12. Kottke TE, Brekke ML, Solberg LI, Hughes JR (1989) A randomized trial to increase smoking intervention by physicians: Doctors Helping Smokers, Round I. Jama 261(14): 2101-2106.

13. Mosbah R, Yousef MI, Mantovani A (2015) Nicotineinduced reproductive toxicity, oxidative damage, histological changes and haematotoxicity in male rats: the protective effects of green tea extract. Exp Toxi Path 67(3): 253-259.

14. Jacobson M, Crosby DG (1971) Naturally occurring insecticides. Naturally occurring insecticides.

15. Tomizawa M, Casida JE (2003) Selective toxicity of neonicotinoids attributable to specificity of insect and mammalian nicotinic receptors. Annu Rev Entomol 48: 339-364.

16. Benowitz NL, Jacob III P (1984) Daily intake of nicotine during cigarette smoking. Clin Pharmacol Ther 35(4): 499-504.

17. Kozlowski LT, Mehta NY, Sweeney CT, Schwartz SS, Vogler GP, et al. (1998) Filter ventilation and nicotine content of tobacco in cigarettes from Canada, the United Kingdom, and the United States. Tob Control 7(4): 369-375. 


\section{International Journal of Biochemistry \& Physiology}

18. Armstrong DW, Wang X, Ercal N (1998) Enantiomeric composition of nicotine in smokeless tobacco, medicinal products, and commercial reagents. Chirality 10(7): 587-591.

19. Klus H, Kuhn H (1977) A study of the optical activity of smoke nicotines. Fachliche Mitt Oesterr Tabakregie 17: 331-336.

20. Pool W, Godin C, Crooks P (1985) Nicotine racemization during cigarette smoking. Toxicologist 5: 232

21. Hukkanen J, Jacob P, Benowitz NL (2005) Metabolism and disposition kinetics of nicotine. Pharmacol Rev 57(1): 79-115.

22. Ashrafizadeh M, Rafiei H, Ahmadi Z (2018) Histological Changes in the Liver and Biochemical Parameters of Chickens Treated with Lead Acetate II. Iran J Toxicol 12(6): 1-5.

23. Jalili C, Tabatabaei H, Kakaberiei S, Roshankhah S, Salahshoor MR (2015) Protective role of Crocin against nicotine-induced damages on male mice liver. Int J Preven Med 6: 92.

24. Conceição E, Peixoto-Silva N, Pinheiro C, Oliveira E, Moura E, et al. (2015) Maternal nicotine exposure leads to higher liver oxidative stress and steatosis in adult rat offspring. Food Chem Toxicol 78: 52-59.

25. Sakr SA (2007) Ameliorative effect of ginger (Zingiber officinale) on mancozeb fungicide induced liver injury in albino rats. Aust J Basic Appl Sci 1(4): 650-656.

26. Dunne M, Yule D, Gallacher D, Petersen O (1990) Effects of alanine on insulin-secreting cells: patchclamp and single cell intracellular $\mathrm{Ca}^{2+}$ measurements. Biochimica et Biophysica Acta (BBA)Molecular Cell Res 1055(2): 157-164.

27. Nadeau KJ, Klingensmith G, Zeitler P (2005) Type 2 diabetes in children is frequently associated with elevated alanine aminotransferase. J Pediat Gastroenterol Nutri 41(1): 94-98.

28. Roohbakhsh A, Parhiz H, Soltani F, Rezaee R, Iranshahi M (2015) Molecular mechanisms behind the biological effects of hesperidin and hesperetin for the prevention of cancer and cardiovascular diseases. Life sciences 124: 64-74.

29. Shafiee-Nick R, Ghorbani A, Vafaee Bagheri F, Rakhshandeh H (2012) Chronic administration of a combination of six herbs inhibits the progression of hyperglycemia and decreases serum lipids and aspartate amino transferase activity in diabetic rats. Advan Pharmacol Sci 6.

30. Zareei S, Boojar MM, Amanlou M (2017) Inhibition of liver alanine aminotransferase and aspartate aminotransferase by hesperidin and its aglycone hesperetin: An in vitro and in silico study. Life Sci 178: 49-55.

31. Salahshoor MR, Roshankhah S, Jafarzadeh AR, Darehdori AS, Jalili C (2015) The Protective Effect Of Crocin On Pancreatic Disorders Resulting From Nicotine Prescription In Male Balb/C Mice.

32. Hemed NM, Convertino A, Shacham-Diamand Y (2018) Alkaline phosphatase detection using electrochemical impedance of anti-alkaline phosphatase antibody (Ab354) functionalized siliconnanowire-forest in phosphate buffer solution. Sensors Actuators B: Chem 259: 809-815.

33. Gill TS, Tewari H, Pande J, Lal S (1991) In vivo tissue enzyme activities in the rosy barb (Barbus conchonius Hamilton) experimentally exposed to lead. Bull Environ Contam Toxicol 47(6): 939-946.

34. Moussa S, Bashandy S (2008) Biophysical and biochemical changes in the blood of rats exposed to lead toxicity. Rom J Biophys 18(2): 123-133.

35. Lallemand F, Ward RJ, Dravolina O, De Witte P (2006) Nicotine-induced changes of glutamate and arginine in naive and chronically alcoholized rats: an in vivo microdialysis study. Brain Res 1111(1): 48-60.

36. Chattopadhyay K, Samanta A, Mukhopadhyay S, Chattopadhyay B (2018) Potential amelioration of nicotine-induced toxicity by nanocurcumin. Drug Dev Res 79(3): 119-128.

37. Frost H (1973) Bone remodeling and its relationship to metabolic bone deseases. Orthopedic lectures 3: 65-75.

38. Rafiei H, Ahmadi Z, Ashrafizadeh M (2018) Effects of Orally Administered Lead acetate II on Rat Femur Histology, Mineralization Properties and Expression of Osteocalcin Gene. Int Bio Biomed J 4(3): 149-155.

39. Ahmadi Z, Ashrafizadeh M (2018) Downregulation of Osteocalcin Gene in Chickens Treated with Lead Acetate II. Int Biol Biomed J 4(4): 0-0. 


\section{International Journal of Biochemistry \& Physiology}

40. Rafiei H, Ashrafizadeh M (2018) Expression of Collagen Type II and Osteocalcin Genes in Mesenchymal Stem Cells from Rats Treated with Lead acetate II. Iranian J Toxi 12(5): 35-40.

41. Rafiei H, Shariati M, Khayatzadeh J, Afsharnezhad S, Farhoodi M (2018) Effects of Oral Dosage of Lead Acetate II on Osteocalcin Gene Expression in Rat Mesenchymal Stem Cells. Reports Biochem Molecular Biol 6(2): 131-136.

42. Jilka RL (2003) Biology of the basic multicellular unit and the pathophysiology of osteoporosis. Med Pediatr Oncol 41(3): 182-185.

43. Health UDo, Services H (2004) The health consequences of smoking: a report of the Surgeon General.

44. Health UDo, Services H (2014) The health consequences of smoking - 50 years of progress: a report of the Surgeon General. Atlanta, GA: US Department of Health and Human Services, Centers for Disease Control and Prevention, National Center for Chronic Disease Prevention and Health Promotion, Office on Smoking and Health: 17.

45. Holmberg T, Bech M, Curtis T, Juel K, Grønbæk M, et al. (2011) Association between passive smoking in adulthood and phalangeal bone mineral density: results from the KRAM study-the Danish Health Examination Survey 2007-2008. Osteoporosis Int 22(12): 2989-2999.

46. Law M, Hackshaw A (1997) A meta-analysis of cigarette smoking, bone mineral density and risk of hip fracture: recognition of a major effect. Bmj 315(7112): 841-846.

47. Sherman CB (1992) The health consequences of cigarette smoking: pulmonary diseases. Med Clin North Ame 76(2): 355-375.

48. Tamaki J, Iki M, Fujita Y, Kouda K, Yura A, et al. (2011) Impact of smoking on bone mineral density and bone metabolism in elderly men: the Fujiwara-kyo Osteoporosis Risk in Men (FORMEN) study. Osteoporosis Int 22(1): 133-141.

49. Adams C, Keating J, Court-Brown C (2001) Cigarette smoking and open tibial fractures. Injury 32(1): 6165.

50. Andersen T, Christensen FB, Laursen M, Høy K, Hansen ES, et al. (2001) Smoking as a predictor of negative outcome in lumbar spinal fusion. Spine 26(23): 2623-2628.

51. Brown CW, Orme TJ, Richardson HD (1986) The rate of pseudarthrosis (surgical nonunion) in patients who are smokers and patients who are nonsmokers: a comparison study. Spine 11(9): 942-943.

52. Chen F, Osterman A, Mahony K (2001) Smoking and bony union after ulna-shortening osteotomy. American journal of orthopedics (Belle Mead, NJ). 30(6): 486-489.

53. Haverstock BD, Mandracchia VJ (1998) Cigarette smoking and bone healing: implications in foot and ankle surgery. J Foot Ankle Surg 37(1): 69-74.

54. Ishikawa SN, Murphy GA, Richardson EG (2002) The effect of cigarette smoking on hindfoot fusions. Foot Ankle Int 23(11): 996-998.

55. Meldrum RD, Wurtz LD, Feinberg JR, Capello WN (2005) Does smoking affect implant survivorship in total hip arthroplasty?: A preliminary retrospective case series. Iowa Ortho J 25: 17-24.

56. Mosely LH, Finseth F (1977) Cigarette smoking: impairment of digital blood flow and wound healing in the hand. Hand 9(2): 97-101.

57. Rajan RA, Ong M, Jones S, Fernandes J (2007) Does smoking affect the quality of bone regenerate in paediatric limb reconstructive surgery?. J Children's Ortho 1(6): 365.

58. Sloan A, Hussain I, Maqsood M, Eremin O, El-Sheemy $M(2010)$ The effects of smoking on fracture healing. Surgeon 8(2): 111-116.

59. Hadley MN, Reddy SV (1997) Smoking and the human vertebral column: a review of the impact of cigarette use on vertebral bone metabolism and spinal fusion. Neurosurgery 41(1): 116-124.

60. Holm S, Nachemson A (1988) Nutrition of the intervertebral disc: acute effects of cigarette smoking: an experimental animal study. Upsala J Med Sci 93(1): 91-99.

61. Schindeler A, McDonald MM, Bokko P, Little DG (2008) Bone remodeling during fracture repair: The cellular picture. Seminars Cell Dev Biol 19(5): 459466. 


\section{International Journal of Biochemistry \& Physiology}

62. Barnes GL, Kostenuik PJ, Gerstenfeld LC, Einhorn TA (1999) Growth factor regulation of fracture repair. J Bone Miner Res 14(11): 1805-1815.

63. Daci E, Everts V, Torrekens S, Van Herck E, Tigchelaar-Gutterr W, et al. (2003) Increased bone formation in mice lacking plasminogen activators. J Bone Miner Res 18(7): 1167-1176.

64. Einhorn TA (1998) The cell and molecular biology of fracture healing. Clin Ortho Relat Res 355: S7-S21.

65. Ogata Y (2008) Bone sialoprotein and its transcriptional regulatory mechanism. J Periodontal Res 43(2): 127-135.

66. Rudäng R, Darelid A, Nilsson M, Nilsson S, Mellström D, et al. (2012) Smoking is associated with impaired bone mass development in young adult men: A 5-year longitudinal study. J Bone Miner Res 27(10): 21892197.

67. Høidrup S, Prescott E, Sørensen TI, Gottschau A, Lauritzen JB, et al. (2000) Tobacco smoking and risk of hip fracture in men and women. Int J Epidemiol 29(2): 253-259.

68. Liang D, Wang KJ, Tang ZQ, Liu RH, Zeng F, et al. (2018) Effects of nicotine on the metabolism and gene expression profile of Sprague-Dawley rat primary osteoblasts. Molec Med Reports 17(6): 82698281.

69. Fang M, Frost P, Iida-Klein A, Hahn T (1991) Effects of nicotine on cellular function in UMR 106-01 osteoblast-like cells. Bone 12(4): 283-286.

70. Marinucci L, Balloni S, Fettucciari K, Bodo M, Talesa VN, et al. (2018) Nicotine induces apoptosis in human osteoblasts via a novel mechanism driven by $\mathrm{H}_{2} \mathrm{O}_{2}$ and entailing Glyoxalase 1-dependent MG-H1 accumulation leading to TG2-mediated NF-kB desensitization: Implication for smokers-related osteoporosis. Free Radi Biol Med 117: 6-17.

71. Sobkowiak R, Lesicki A (2013) Absorption, metabolism and excretion of nicotine in humans. Postepy Biochem 59(1): 33-44.

72. Schoedel KA, Tyndale RF (2003) Induction of nicotine-metabolizing CYP2B1 by ethanol and ethanol-metabolizing CYP2E1 by nicotine: summary and implications. Biochim Biophys Acta 1619(3): 283-290.
73. Arany I, Hall S, Reed DK, Reed CT, Dixit M (2016) Nicotine enhances high-fat diet-induced oxidative stress in the kidney. Nicotine Tobacco Res 18(7): 1628-1634.

74. Benowitz NL, Burbank AD (2016) Cardiovascular toxicity of nicotine: implications for electronic cigarette use. Trends Cardiovas Med 26(6): 515-523.

75. Das S, Prochaska JJ (2017) Innovative approaches to support smoking cessation for individuals with mental illness and co-occurring substance use disorders. Expert Rev Respi Med 11(10): 841-850.

76. Bonventre JV, Vaidya VS, Schmouder R, Feig P, Dieterle F (2010) Next-generation biomarkers for detecting kidney toxicity. Nat Biotechnol 28(5): 436440.

77. Zahran WE, Emam MA (2018) Renoprotective effect of Spirulina platensis extract against nicotine-induced oxidative stress-mediated inflammation in rats. Phytomed 49: 106-110.

78. Mahmoud GS, Amer AS (2014) Protective effects of vitamin $C$ against nicotine-induced oxidative damage of rat liver and kidney. IOSR-JESTFT 8(12): 50-63.

79. Storey KB (1996) Oxidative stress: animal adaptations in nature. Braz J Med Bio Res 29(12): 1715-1733.

80. Mladěnka P, Applová L, Patočka J, Costa VM, Remiao $\mathrm{F}$, et al. (2018) Comprehensive review of cardiovascular toxicity of drugs and related agents. Med Res Rev 38(4): 1332-1403.

81. Pinto AR, Da Silva NC, Pinato L (2016) Analyses of melatonin, cytokines, and sleep in chronic renal failure. Sleep Breath 20(1): 339-344.

82. Yan W, Li R, He J, Du J, Hou J (2015) Importin $\beta 1$ mediates nuclear factor- $\mathrm{\kappa B}$ signal transduction into the nuclei of myeloma cells and affects their proliferation and apoptosis. Cell Signal 27(4): 851859.

83. Wang M, Li Y, Ni C, Song G (2017) Honokiol attenuates oligomeric amyloid $\beta 1$-42-induced Alzheimer's disease in mice through attenuating mitochondrial apoptosis and inhibiting the nuclear factor kappa-B signaling pathway. Cell Physiol Biochem 43(1): 69-81. 


\section{International Journal of Biochemistry \& Physiology}

84. Guijarro C, Egido J (2001) Transcription factor- $\kappa B$ (NF-кB) and renal disease. Kidney Int 59(2): 415-424.

85. Parikh SM, Pollak MR (20101) VEGF receptors and glomerular function. J Ame Soc Nephrol 21(10): 1599-1600.

86. Janus P, Szołtysek K, Zając G, Stokowy T, Walaszczyk A, et al. (2018) Pro-inflammatory cytokine and high doses of ionizing radiation have similar effects on the expression of NF-kappaB-dependent genes. Cell Signal 46: 23-31.

87. Du X, Qi F, Lu S, Li Y, Han W (2018) Nicotine upregulates FGFR3 and RB1 expression and promotes non-small cell lung cancer cell proliferation and epithelial-to-mesenchymal transition via downregulation of miR-99b and miR-192. Biomed Pharma 101: 656-662.

88. Waldum HL, Nilsen OG, Nilsen T, Rørvik H, Syversen $\mathrm{U}$, et al. (1996) Long-term effects of inhaled nicotine. Life Sci 58(16): 1339-1346.

89. Cucina A, Dinicola S, Coluccia P, Proietti S, D'Anselmi F, et al. (2012) Nicotine stimulates proliferation and inhibits apoptosis in colon cancer cell lines through activation of survival pathways. J Surg Res 178(1): 233-241.

90. Jensen K, Afroze S, Munshi MK, Guerrier M, Glaser SS (2012) Mechanisms for nicotine in the development and progression of gastrointestinal cancers. Trans Gastro Cancer 1(1): 81-87.

91. Schaal C, Chellappan SP (2014) Nicotine-mediated cell proliferation and tumor progression in smokingrelated cancers. Mol Cancer Res 12(1): 14-23.

92. Nair S, Bora-Singhal N, Perumal D, Chellappan S (2014) Nicotine-mediated invasion and migration of non-small cell lung carcinoma cells by modulating STMN3 and GSPT1 genes in an ID1-dependent manner. Mol Cancer 13: 173.

93. Davis R, Rizwani W, Banerjee S, Kovacs M, Haura E, et al. (2009) Nicotine promotes tumor growth and metastasis in mouse models of lung cancer. PloS one 4(10): e7524.

94. Czyżykowski R, Połowinczak-Przybyłek J, Potemski P (2016) Nicotine-induced resistance of non-small cell lung cancer to treatment-possible mechanisms. Postepy Hig Med Dosw 70: 186-193.
95. Egleton RD, Brown KC, Dasgupta P (2008) Nicotinic acetylcholine receptors in cancer: multiple roles in proliferation and inhibition of apoptosis. Trends Pharmacol Sci 29(3): 151-158.

96. Improgo MR, Tapper AR, Gardner PD (2011) Nicotinic acetylcholine receptor-mediated mechanisms in lung cancer. Biochem Pharmacol 82(8): 1015-1021.

97. Yildiz A, Vardi N, Karaaslan M, Ates B, Taslidere E, et al. (2018) The protective effect of melatonin in lungs of newborn rats exposed to maternal nicotine. Biotechnic Histochem 93(6): 442-452.

98. Boehme AK, Esenwa C, Elkind MS (2017) Stroke risk factors, genetics, and prevention. Circulation Res 120(3): 472-495.

99. Peters SA, Huxley RR, Woodward M (2013) Smoking as a risk factor for stroke in women compared with men: A systematic review and meta-analysis of 81 cohorts, including 3980359 individuals and 42401 strokes. Stroke 44(10): 2821-2828.

100. Ohno K, Pettigrew K, Rapoport S (1979) Local cerebral blood flow in the conscious rat as measured with 14C-antipyrine, 14C-iodoantipyrine and 3Hnicotine. Stroke 10(1): 62-67.

101. Suzuki R, Nitsch C, Fujiwara K, Klatzo I (1984) Regional Changes in Cerebral Blood Flow and Blood-Brain Barrier Permeability during Epileptiform Seizures and in Acute Hypertension in Rabbits. J Cereb Blood Flow Metab 4(1): 96-102.

102. Tomiyama Y, Brian JE, Todd MM (1999) Cerebral blood flow during hemodilution and hypoxia in rats: role of ATP-sensitive potassium channels. Stroke 30(9): 1942-1948.

103. Flood P, Daniel D (2004) Intranasal nicotine for postoperative pain treatment. Anesthesiology 101(6): 1417-1421.

104. Habib AS, White WD, El Gasim MA, Saleh G, Polascik TJ, et al. (2008) Transdermal nicotine for analgesia after radical retropubic prostatectomy. Anesthesia Analgesia 107(3): 999-1004.

105. Rune G, Frotscher M (2005) Neurosteroid synthesis in the hippocampus: role in synaptic plasticity. Neurosci 136(3): 833-842.

106. Dubal DB, Rau SW, Shughrue PJ, Zhu H, Yu J, et al. (2006) Differential modulation of estrogen receptors 


\section{International Journal of Biochemistry \& Physiology}

(ERs) in ischemic brain injury: a role for ER $\alpha$ in estradiol-mediated protection against delayed cell death. Endocrinol 147(6): 3076-3084.

107. Lebesgue D, Chevaleyre V, Zukin RS, Etgen AM (2009) Estradiol rescues neurons from global ischemia-induced cell death: multiple cellular pathways of neuroprotection. Steroids 74(7): 555561.

108. Zhang QG, Raz L, Wang R, Han D, De Sevilla L, et al. (2009) Estrogen attenuates ischemic oxidative damage via an estrogen receptor $\alpha$-mediated inhibition of NADPH oxidase activation. J Neurosci 29(44): 13823-13836.

109. d'Adesky ND, de Rivero Vaccari JP, Bhattacharya $P$, Schatz M, Perez-Pinzon MA, et al. (2018) Nicotine alters estrogen receptor-Beta-regulated Inflammasome activity and exacerbates ischemic brain damage in female rats. Int J Mol Sci 19(5).

110. Everitt BJ, Robbins TW (2005) Neural systems of reinforcement for drug addiction: from actions to habits to compulsion. Nature Neurosci 8(11): 14811489.

111. Franklin TR, Wang J, Sciortino N, Harper D, Li Y, et al. (2007) Limbic activation to cigarette smoking cues independent of nicotine withdrawal: a perfusion fMRI study. Neuropsychopharmacology 32(11): 2301-2309.

112. Kühn S, Gallinat J (2011) Common biology of craving across legal and illegal drugs-a quantitative meta-analysis of cue-reactivity brain response. Eur J Neurosci 33(7): 1318-1326.

113. Rubinstein ML, Luks TL, Moscicki AB, Dryden W, Rait MA, et al. (2011) Smoking-related cue-induced brain activation in adolescent light smokers. J Adolesc Heal 48(1): 7-12.

114. Stippekohl B, Winkler M, Mucha RF, Pauli P, Walter B, et al. (2010) Neural responses to BEGIN-and ENDstimuli of the smoking ritual in nonsmokers, nondeprived smokers, and deprived smokers. Neuropsychopharmacology 35(5): 1209-1225.

115. Dschietzig T, Brecht A, Bartsch C, Baumann G, Stangl $\mathrm{K}$, et al. (2012) Relaxin improves TNF- $\alpha$-induced endothelial dysfunction: the role of glucocorticoid receptor and phosphatidylinositol 3-kinase signalling. Cardiovascular Res 95(1): 97-107.
116. Shen Z, Huang P, Wang C, Qian W, Luo X, et al. (2017) Altered function but not structure of the amygdala in nicotine-dependent individuals. Neuropsychologia 107: 102-107.

117. Garrido R, King-Pospisil K, Son KW, Hennig B, Toborek M (2003) Nicotine upregulates nerve growth factor expression and prevents apoptosis of cultured spinal cord neurons. Neurosci Res 47(3): 349-355.

118. Takahashi T, Yamashita $\mathrm{H}$, Nakamura S, Ishiguro $\mathrm{H}$, Nagatsu T, et al. (1999) Effects of nerve growth factor and nicotine on the expression of nicotinic acetylcholine receptor subunits in PC12 cells. Neurosci Res 35(3): 175-181.

119. Terry Jr AV, Clarke MS (1994) Nicotine stimulation of nerve growth factor receptor expression. Life Sci 55(5): PL91-PL8.

120. Freund-Michel V, Frossard N (2008) The nerve growth factor and its receptors in airway inflammatory diseases. Pharmacol Therap 117(1): $52-76$.

121. Prakash Y, Thompson MA, Meuchel L, Pabelick CM, Mantilla CB, et al. (2010) Neurotrophins in lung health and disease. Expert Rev Resp Med 4(3): 395411.

122. Sonar S, Schwinge D, Kilic A, Yildirim A, Conrad M, et al. (2010) Nerve growth factor enhances Clara cell proliferation after lung injury. Eur Resp J 36: 105115.

123. Urrego F, Scuri M, Auais A, Mohtasham L, Piedimonte G (2009) Combined effects of chronic nicotine and acute virus exposure on neurotrophin expression in rat lung. Pediatr pulmonol 44(11): 1075-1084.

124. Wongtrakool C, Grooms K, Bijli KM, Crothers K, Fitzpatrick AM, et al. (2014) Nicotine stimulates nerve growth factor in lung fibroblasts through an NFKB-dependent mechanism. Plos one 9(10): e109602.

125. Stabile A, Marinucci L, Balloni S, Giuliani A, Pistilli A, et al. (2018) Long term effects of cigarette smoke extract or nicotine on nerve growth factor and its receptors in a bronchial epithelial cell line. Toxicol Vitro 53: 29-36. 


\section{International Journal of Biochemistry \& Physiology}

126. Changeux JP (2010) Nicotine addiction and nicotinic receptors: lessons from genetically modified mice. Nat Rev Neurosci 11(6): 389-401.

127. Dwyer JB, McQuown SC, Leslie FM (2009) The dynamic effects of nicotine on the developing brain. Pharmacol Ther 122(2): 125-139.

128. Melroy-Greif WE, Stitzel JA, Ehringer MA (2016) Nicotinic acetylcholine receptors: upregulation, age-related effects and associations with drug use. Genes Brain Behavior 15(1): 89-107.

129. Pauly JR, Slotkin TA (2008) Maternal tobacco smoking, nicotine replacement and neurobehavioural development. Acta Paediatrica 97(10): 1331-1337.

130. Liu W, Porter NA, Schneider C, Brash AR, Yin H (2011) Formation of 4-hydroxynonenal from cardiolipin oxidation: intramolecular peroxyl radical addition and decomposition. Free Radical Biol Med 50(1): 166-178.

131. Slotkin TA (2004) Cholinergic systems in brain development and disruption by neurotoxicants: nicotine, environmental tobacco smoke, organophosphates. Toxicol Appl Pharmacol 198(2): 132-151.

132. Slotkin TA (2008) If nicotine is a developmental neurotoxicant in animal studies, dare we recommend nicotine replacement therapy in pregnant women and adolescents?. Neurotoxicol Teratol 30(1): 1-19.

133. Velazquez-Ulloa NA (2017) A Drosophila model for developmental nicotine exposure. PloS one 12(5): e0177710.

134. Muhammad A, Mychasiuk R, Nakahashi A, Hossain SR, Gibb R, et al. (2012) Prenatal nicotine exposure alters neuroanatomical organization of the developing brain. Synapse 66(11): 950-954.

135. Roy T, Sabherwal U (1998) Effects of gestational nicotine exposure on hippocampal morphology. Neurotoxicol Teratol 20(4): 465-473.

136. Santiago SE, Huffman KJ (2012) Postnatal effects of prenatal nicotine exposure on body weight, brain size and cortical connectivity in mice. Neurosci Res 73(4): 282-291.
137. Alkam T, Kim HC, Mamiya T, Yamada K, Hiramatsu M, et al. (2013) Evaluation of cognitive behaviors in young offspring of C57BL/6J mice after gestational nicotine exposure during different time-windows. Psychopharmacol 230(3): 451-463.

138. Alkam T, Mamiya T, Kimura N, Yoshida A, Kihara D, et al. (2017) Prenatal nicotine exposure decreases the release of dopamine in the medial frontal cortex and induces atomoxetine-responsive neurobehavioral deficits in mice. Psychopharmacology 234(12): 1853-1869.

139. Money KM, Stanwood GD (2013) Developmental origins of brain disorders: roles for dopamine. Front Cell Neurosci 7: 260.

140. Muneoka K, Nakatsu T, Fuji JI, Ogawa T, Takigawa M (1999) Prenatal administration of nicotine results in dopaminergic alterations in the neocortex. Neurotoxicol Teratol 21(5): 603-609.

141. Navarro HA, Seidler FJ, Whitmore WL, Slotkin TA (1988) Prenatal exposure to nicotine via maternal infusions: effects on development of catecholamine systems. J Pharmacol Exp Ther 244(3): 940-944.

142. Ribary U, Lichtensteiger W (1989) Effects of acute and chronic prenatal nicotine treatment on central catecholamine systems of male and female rat fetuses and offspring. J Pharmacol Exp Ther 248(2):786-792.

143. Richardson SA, Tizabi Y (1994) Hyperactivity in the offspring of nicotine-treated rats: role of the mesolimbic and nigrostriatal dopaminergic pathways. Pharmacol Biochem Behav 47(2): 331337.

144. Zhu J, Zhang X, Xu Y, Spencer TJ, Biederman J, et al. (2012) Prenatal nicotine exposure mouse model showing hyperactivity, reduced cingulate cortex volume, reduced dopamine turnover, and responsiveness to oral methylphenidate treatment. J Neurosci 32(27): 9410-9418.

145. Morris M, Shaw A, Lambert M, Perry HH, Lowenstein E, et al. (2018) Developmental nicotine exposure affects larval brain size and the adult dopaminergic system of Drosophila melanogaster. BMC Dev Biol 18(1): 13.

146. Abdollahzadeh Soreshjani S, Ashrafizadeh M (2018) The Effects of the Exercise on the Testosterone Level, 


\section{International Journal of Biochemistry \& Physiology}

Heat Shock Proteins and Fertility Potential. Rev Clin Med 5(4): 141-145.

147. Harlev A, Agarwal A, Gunes SO, Shetty A, du Plessis SS (2015) Smoking and male infertility: an evidencebased review. World J Men's Heal 33(3): 143-160.

148. Lagunov A, Anzar M, Sadeu JC, Khan MIR, Bruin JE, et al. (2011) Effect of in utero and lactational nicotine exposure on the male reproductive tract in peripubertal and adult rats. Reprod Toxicol 31(4): 418-423.

149. Jana K, Samanta PK, De DK (2010) Nicotine diminishes testicular gametogenesis, steroidogenesis, and steroidogenic acute regulatory protein expression in adult albino rats: possible influence on pituitary gonadotropins and alteration of testicular antioxidant status. Toxicol Sci 116(2): 647-659.

150. Carvalho C, Favaro W, Padovani C, Cagnon V (2006) Morphometric and ultrastructure features of the ventral prostate of rats (Rattus norvegicus) submitted to long-term nicotine treatment. Andrologia 38(4): 142-151.

151. El-Aziz GSA, El-Fark MO, Hamdy RM (2016) Protective effect of Eruca sativa seed oil against oral nicotine induced testicular damage in rats. Tissue Cell 48(4): 340-348.

152. Oyeyipo IP, Raji Y, Bolarinwa AF (2013) Nicotine alters male reproductive hormones in male albino rats: the role of cessation. J Human Reproduc Sci 6(1): 40-44.

153. Mohammadghasemi F, Jahromi SK, Hajizadeh H, Homafar MA, Saadat N (2012) The protective effects of exogenous melatonin on nicotine-induced changes in mouse ovarian follicles. J Reprod Infertil 13(3): $143-150$.

154. Saadat SNS, Mohammadghasemi F, Jahromi SK, Homafar MA, Haghiri M (2014) Melatonin protects uterus and oviduct exposed to nicotine in mice. Interdisciplinary Toxicol 7(1): 41-46.

155. Oyeyipo I, Raji Y, Bolarinwa A (2014) Antioxidant profile changes in reproductive tissues of rats treated with nicotine. J Human Reprod Sci 7(1): 4146.

156. Reddy A, Sood A, Rust PF, Busby JE, Varn E, et al. (1995) The effect of nicotine onin vitro sperm motion characteristics. J Assist Reprod Genet 12(3): 217-223.

157. Kim KH, Joo KJ, Park HJ, Kwon CH, Jang MH, et al. (2005) Nicotine induces apoptosis in TM3 mouse Leydig cells. Fertility Sterility 83: 1093-1099.

158. Nie D, Zhang D, Dai J, Zhang M, Zhao X, et al. (2016) Nicotine induced murine spermatozoa apoptosis via up-regulation of deubiquitinated RIP1 by Trim27 promoter hypomethylation. Biol Reprod 94(2): 31.

159. Oyeyipo I, Raji Y, Emikpe B, Bolarinwa A (2010) Effects of oral administration of nicotine on organ weight, serum testosterone level and testicular histology in adult male rats. Niger J Physiol Sci 25(1): 81-86.

160. Oyeyipo IP, Raji Y, Emikpe BO, Bolarinwa AF (2011) Effects of nicotine on sperm characteristics and fertility profile in adult male rats: a possible role of cessation. J Reprod Infertility 12(3): 201-207.

161. Aydos K, Güven M, Can B, Ergün A (2001) Nicotine toxicity to the ultrastructure of the testis in rats. BJU Int 88(6): 622-626.

162. Malm G, Haugen TB, Rylander L, Giwercman A (2017) Seasonal fluctuation in the secretion of the antioxidant melatonin is not associated with alterations in sperm DNA damage. Asian J Androl 19(1): 52-56.

163. Mohammadghasemi F, Khajeh Jahromi S (2018) Melatonin ameliorates testicular damages induced by nicotine in mice. Iran J Basic Med Sci 21(6): 639644.

164. Aitken RJ, Koopman P, Lewis SE (2004) Seeds of concern. Nature 432: 48-52.

165. Sakkas D, Urner F, Bizzaro D, Manicardi G, Bianchi P, et al. (1998) Sperm nuclear DNA damage and altered chromatin structure: effect on fertilization and embryo development. Hum Reprod 13(4): 11-19.

166. Li S, Lu D, Zhang Y, Zhang Y (2014) Long-term treatment of hydrogen-rich saline abates testicular oxidative stress induced by nicotine in mice. J Assisted Reprod Genetics 31(1): 109-114.

167. Cheng CY, Mruk DD (2002) Cell junction dynamics in the testis: Sertoli-germ cell interactions and male contraceptive development. Physiol Rev 82(4): 825874. 


\section{International Journal of Biochemistry \& Physiology}

168. Mruk DD, Cheng CY (2004) Sertoli-Sertoli and Sertoli-germ cell interactions and their significance in germ cell movement in the seminiferous epithelium during spermatogenesis. Endo Rev 25(5): 747-806.

169. Bergen AW, Javitz HS, Krasnow R, Michel M, Nishita D, et al. (2014) Organic cation transporter variation and response to smoking cessation therapies. Nicotine Tob Res 16(12): 1638-1646.

170. Syam Das S, Nair S, Indira M (2018) Atorvastatin modulates drug transporters and ameliorates nicotine-induced testicular toxicity. Andrologia 50(6): e13029.

171. Baker PJ, Pakarinen P, Huhtaniemi IT, Abel MH, Charlton HM, et al. (2003) Failure of normal Leydig cell development in follicle-stimulating hormone (FSH) receptor-deficient mice, but not FSH $\beta$ deficient mice: role for constitutive FSH receptor activity. Endocrinol 144(1): 138-145.

172. Liu HC, Zhu D, Wang C, Guan H, Li S, et al. (2015) Effects of etomidate on the steroidogenesis of rat immature Leydig cells. PloS one 10(11): e0139311.

173. Guo X, Wang H, Wu X, Chen X, Chen Y, et al. (2017) Nicotine affects rat Leydig cell function in vivo and vitro via down-regulating some key steroidogenic enzyme expressions. Food Chem Toxicol 110:13-24.

174. Gotti C, Clementi F (2004) Neuronal nicotinic receptors: from structure to pathology. Prog Neurobiol 74(6): 363-396.

175. Ge RS, Dong Q, Sottas CM, Chen H, Zirkin BR, et al. (2005) Gene expression in rat Leydig cells during development from the progenitor to adult stage: a cluster analysis. Biol Reprod 72(6): 1405-1415.

176. Favaretto A, Valenca M, Picanço-Diniz D, AntunesRodrigues J (1993) Inhibitory role of cholinergic agonists on testosterone secretion by purified rat Leydig cells. Arch Int Phy Biochim Biophys 101(6): 333-335.

177. Control CFD (2008) Smoking prevalence among women of reproductive age--United States, 2006. MMWR 57(31): 849-852.

178. Huisman M, Kunst A, Mackenbach J (2005) Educational inequalities in smoking among men and women aged 16 years and older in 11 European countries. Tob Cont 14(2): 106-113.
179. Ashford K, Rayens E, Wiggins AT, Kay Rayens M, Sayre MM, et al. (2018) Associations of Demographic Factors and Tobacco Use With Progesterone and Estradiol During Pregnancy. SAGE Open Nursing 4: $1-6$.

180. Barbieri RL, Gochberg J, Ryan KJ (1986) Nicotine, cotinine, and anabasine inhibit aromatase in human trophoblast in vitro. J Clin Inv 77(6): 1727-1733.

181. Cramer DW, Harlow BL, Xu H, Fraer C, Barbieri R (1995) Cross-sectional and case-controlled analyses of the association between smoking and early menopause. Maturitas 22(2): 79-87.

182. Crandall CJ, Markovic D, Huang MH, Greendale GA (2010) Predictors of breast discomfort among women initiating menopausal hormone therapy. Menopause 17(3): 462-470.

183. Grainge M, Coupland C, Cliffe S, Chilvers C, Hosking D, et al. (1998) Cigarette smoking, alcohol and caffeine consumption, and bone mineral density in postmenopausal women. Osteoporosis Int 8(4): 355363.

184. Greenberg G, Thompson S, Meade T (1987) Relation between cigarette smoking and use of hormonal replacement therapy for menopausal symptoms. J Epidemiol Commun Health 41(1): 26-29.

185. Jensen J, Christiansen C, Rødbro P (1985) Cigarette smoking, serum estrogens, and bone loss during hormone-replacement therapy early after menopause. New Eng J Med 313(16): 973-975.

186. Michnovicz JJ, Naganuma H, Hershcopf RJ, Bradlow HL, Fishman J (1988) Increased urinary catechol estrogen excretion in female smokers. Steroids 52(12): 69-83.

187. Windham GC, Elkin E, Swan S, Waller K, Fenster L (1999) Cigarette smoking and effects on menstrual function. Obstetrics Gynecol 93(1): 59-65.

188. Lips K, Brüggmann D, Pfeil U, Vollerthun R, Grando S, et al. (2005) Nicotinic acetylcholine receptors in rat and human placenta. Placenta 26(10): 735-746.

189. Benedict MD, Missmer SA, Vahratian A, Berry KF, Vitonis AF, et al. (2011) Secondhand tobacco smoke exposure is associated with increased risk of failed implantation and reduced IVF success. Hum Reprod 26(9): 2525-2531. 


\section{International Journal of Biochemistry \& Physiology}

190. Dechanet C, Anahory T, Mathieu Daude J, Quantin X, Reyftmann L, et al. (2010) Effects of cigarette smoking on reproduction. Hum Reprod Update 17(1): 76-95.

191. Soares S, Simon C, Remohi J, Pellicer A (2006) Cigarette smoking affects uterine receptiveness. Hum Reprod 22(2): 543-547.

192. Zdravkovic T, Genbacev O, LaRocque N, McMaster M, Fisher S (2008) Human embryonic stem cells as a model system for studying the effects of smoke exposure on the embryo. Reprod Toxicol 26(2): 8693.

193. Jin Z, Roomans G (1997) Effects of nicotine on the uterine epithelium studied by X-ray microanalysis. J Submicros Cytol Pathol 29(2): 179-186.

194. Jin Z, Jin M, Roomans GM (1994) Effect of extracellular $\mathrm{K}+$ on hatching and outgrowth of mouse blastocysts in vitro. Cell Biol Int 18(9): 897901.

195. Card J, Mitchell JA (1978) The effects of nicotine administration on deciduoma induction in the rat. Biol Reprod 19(2): 326-331.

196. Yang J, Shi SQ, Shi L, Liu H, Fang D, et al. (2014) Nicotine treatment prolongs gestation and inhibits cervical ripening in pregnant rats. Ame J Obstetrics Gynecol 210(1): 76. e1-7.

197. Iranloye B, Bolarinwa A (2009) Effect of nicotine administration on weight and histology of some vital visceral organs in female albino rats. Nig J Physiol Sci 24(1): 7-12.

198. Halder S, Trauth S, Pearce AR (2015) Oral nicotine alters uterine histo-morphology but does not disrupt the estrous cycle in female rats. Nicotine Tob Res 18(5): 590-595.

199. Magers T, Talbot P, DiCarlantonio G, Knoll M, Demers D, et al. (1995) Cigarette smoke inhalation affects the reproductive system of female hamsters. Reprod Toxicol 9(6): 513-25.

200. Neri A, Eckerling B (1969) Influence of smoking and adrenaline (epinephrine) on the uterotubal insufflation test (Rubin test). Fertility Sterility 20(5): 818-828.

201. Patil S, Patil S, Bhaktaraj B, Patil SB (1999) Effect of graded doses of nicotine on ovarian and uterine activities in albino rats. Indian J Exp Biol 37(2): 184186.

202. Patil SR, Ravindra S, Patil R, Londonkar R, Patil SB (1998) Nicotine induced ovarian and uterine changes in albino mice. Indian J Physiol Pharmacol 42(4): 503-508.

203. Audi SS, Abraham ME, Borker AS (2006) Effect of cigarette smoke on body weight, food intake and reproductive organs in adult albino rats. Indian J Exp Biol 44(7): 562-565.

204. Control CFD (2010) How tobacco smoke causes disease: The biology and behavioral basis for smoking-attributable disease: A report of the surgeon general.

205. Jha P, Ramasundarahettige C, Landsman V, Rostron $\mathrm{B}$, Thun M, et al. (2013) 21st-century hazards of smoking and benefits of cessation in the United States. New Eng J Med 368(4): 341-350.

206. Flouris AD, Faught BE, Klentrou P (2008) Cardiovascular disease risk in adolescent smokers: evidence of asmoker lifestyle'. J Child Heal Care 12(3): 221-231.

207. De Kesel PM, Lambert WE, Stove CP (2016) Alternative sampling strategies for cytochrome P450 phenotyping. Clin Pharmacokin 55(2): 169-184.

208. Fagen ZM, Mansvelder HD, Keath JR, McGEHEE DS (2003) Short-and long-term modulation of synaptic inputs to brain reward areas by nicotine. Annals New York Academy Sci 1003(1): 185-195.

209. Ginzel K, Maritz GS, Marks DF, Neuberger M, Pauly JR, et al. (2007) Critical review: nicotine for the fetus, the infant and the adolescent?. J Heal Psychol 12(2): 215-224.

210. Chen WY, Lee RT (2012) Endothelial cardiac cell therapy: large-animal studies and the elephant in the room. Circ Res 111(7): 824-826.

211. Higashi Y, Sasaki S, Nakagawa K, Matsuura H, Oshima $\mathrm{T}$, et al. (2002) Endothelial function and oxidative stress in renovascular hypertension. New Eng J Med 346(25): 1954-1962.

212. Chen Z, Wen L, Martin M, Hsu C-Y, Fang L, et al. (2015) Oxidative stress activates endothelial innate immunity via sterol regulatory element binding 


\section{International Journal of Biochemistry \& Physiology}

protein 2 (SREBP2) transactivation of microRNA92a. Circulation 131(9): 805-814.

213. Steyers C, Miller F (2014) Endothelial dysfunction in chronic inflammatory diseases. Int J Molec Sci 15(7): 11324-11349.

214. Sun HX, Zeng DY, Li RT, Pang RP, Yang H, et al. (2012) Essential role of microRNA-155 in regulating endothelium-dependent vasorelaxation by targeting endothelial nitric oxide synthase. Hypertension 60(6): 1407-1414.

215. Liu C, Zhou MS, Li Y, Wang A, Chadipiralla K, et al. (2017) Oral nicotine aggravates endothelial dysfunction and vascular inflammation in dietinduced obese rats: Role of macrophage TNF $\alpha$. PloS one 12(12): e0188439.

216. Jiang ZY, Woollard AC, Wolff SP (1990) Hydrogen peroxide production during experimental protein glycation. Febs Lett 268(1): 69-71.

217. Mockett RJ, Sohal RS, Orr WC (1999) Overexpression of glutathione reductase extends survival in transgenic Drosophila melanogaster under hyperoxia but not normoxia. FASEB J 3(13): 17331742.

218. Orr WC, Sohal RS (1994) Extension of life-span by overexpression of superoxide dismutase and catalase in Drosophila melanogaster. Science 263(5150): 1128-1130.

219. Finkel T, Holbrook NJ (2000) Oxidants, oxidative stress and the biology of ageing. Nature 408(6809): 239-247.

220. Flora SJ (2001) Arsenic-induced oxidative stress and its reversibility. Free Radical Biol Med 51(2): $257-$ 281.
221. Mates J (2000) Effects of antioxidant enzymes in the molecular control of reactive oxygen species toxicology. Toxicol 153(1-3): 83-104.

222. Frayn KN (1998) Regulation of fatty acid delivery in vivo. Skeletal Muscle Metab Exercise Diabe: 171-179.

223. Grant LD (2009) Lead and compounds. Environ Toxica: Hum Exposu Heal Effects. $3^{\text {rd }}$ (Edn.), pp: 757809.

224. Baranowska-Bosiacka I, Gutowska I, Rybicka M, Nowacki P, Chlubek D (2012) Neurotoxicity of lead. Hypothetical molecular mechanisms of synaptic function disorders. Neurol Neurochir Pol 46(6): 569578.

225. Benedetti A, Comporti M, Esterbauer H (1980) Identification of 4-hydroxynonenal as a cytotoxic product originating from the peroxidation of liver microsomal lipids. Biochim Biophys Acta 620(2): 281-296.

226. Carmignani M, Volpe AR, Boscolo P, Qiao N, Di Gioacchino M, et al. (2000) Catcholamine and nitric oxide systems as targets of chronic lead exposure in inducing selective functional impairment. Life Sci 68(4): 401-415.

227. Levonen AL, Hill BG, Kansanen E, Zhang J, DarleyUsmar VM (2014) Redox regulation of antioxidants, autophagy, and the response to stress: implications for electrophile therapeutics. Free Radical Biol Med 71: 196-207.

228. Vance JE, Vance DE (2008) Biochemistry of lipids, lipoproteins and membranes. Elsevier. 